\title{
PENGARUH PELAKSANAAN PEMILU PRESIDEN INDONESIA TAHUN 2019 TERHADAP RETURN SAHAM JII70 DI INDONESIA
}

\author{
Erika Adevia Fendiyani (1) Dewi Zulia Kunthi(2) \\ Kharis Fadlullah Hana (3) \\ IAIN Kudus (1), IAIN Kudus (2) , IAIN Kudus (3)
}

\section{Jl. Conge Ngembalrejo Bae Kudus 51 Jawa tengah | erikaadeviaf@gmail.com,1 dewizulia456@gmail.com ${ }^{2}, \underline{\text { kharis@iainkudus.ac.id }{ }^{3}}$}

\begin{abstract}
Abstrak : Pasar modal sebagai salah satu instrumen ekonomi tidak terlepas dari pengaruh lingkungan, baik lingkungan ekonomi maupun lingkungan non-ekonomi. Peristiwa politik merupakan salah satu risiko nonekonomi yang dapat mempengaruhi keputusan investor untuk berinvestasi di pasar modal. Tujuan artikel ini untuk mengetahui pengaruh pemilu presiden Indonesia tahun 2019 terhadap return saham ketika akan ditentukannya bakal calon presiden sebelum pelaksanaan pemilihan umum presiden, pada saat pelaksanaan, dan juga sesudah pelaksanaannya terhadap saham-saham yang terdaftar didalam indeks JII70. Populasi dalam penelitian ini adalah perusahaan yang sahamnya tercatat didalam indeks JII70. Penelitian ini menggunakan even study (studi peristiwa). Hasil penelitian menunjukkan bahwa ada reaksi investor di mana 7 hari sebelum dan 7 hari sesudah tanggal 17 April 2019 pemilu serentak. Penelitian ini menunjukkan bahwa peristiwa pemilu presiden pada tahun 2019 menunjukkan hasil yang cukup signifikan terhadap return dan harga saham dibeberapa perusahaan yang tergabung di indeks JII70.
\end{abstract}

Keywords: Pasar Modal, Return, Pemilu Presiden 


\section{Pendahuluan}

Pasar modal merupakan salah satu instrumen yang berkaitan erat dengan kondisi perekonomian suatu negara. Pasar modal tidak terlepas dari pengaruh suatu peristiwa yang terjadi di lingkungannya, baik lingkungan ekonomi maupun lingkungan non ekonomi (Alrhafynza \& Siswanto, 2017). Adapun lingkungan non ekonomi mencakup berbagai isu tentang kepedulian pada lingkungan hidup, hak asasi manusia, serta peristiwa politik yang seringkali menjadi faktor utama penyebab fluktuasi harga saham di bursa efek seluruh dunia. Bila posisi bursa saham dalam kegiatan ekonomi semakin penting, maka bursa akan semakin sensitif terhadap berbagai peristiwa yang sedang terjadi disekitarnya, baik peristiwa yang berkaitan atau tidak berkaitan secara langsung dengan isu ekonomi (Diniar dan Kiryanto 2015). Salah satu faktor lingkungan non ekonomi yang mempengaruhi perkembangan dalam pasar modal yaitu pelaksanaan pemilu. Dalam suatu negara, pelaksanaan pemilu merupakan salah satu peristiwa politik yang dapat mempengaruhi keputusan investor dalam berinvestasi di pasar modal (Katti, 2018).

Kegiatan jual-beli saham di bursa efek menjadi bagian dari aktivitas ekonomi yang rawan terhadap pengaruh peristiwa politik. Peristiwa politik memang tidak menerobos bursa saham secara langsung, tetapi peristiwa ini merupakan salah satu informasi yang didapat oleh para investor dan digunakan oleh mereka untuk memperoleh keuntungan yang diinginkan di masa yang akan datang (Mentayani 2016).

Indonesia sendiri telah melakukan pemilihan presiden pada 17 April 2019, dimana pemilihan presiden ini adalah salah satu peristiwa politik yang berdampak secara makro terhadap perekonomian suatu negara. Meskipun pemilu 
presiden merupakan peristiwa non ekonomi, namun kegiatan ini memiliki pengaruh yang besar terhadap arah kebijakan karena akan memberikan gambaran atau arah perekonomian dimasa mendatang. Peristiwa pemilu ini menjadi sangat penting karena harga saham yang cenderung berubah serta arah investasi para investor yang mengakibatkan mereka hanya akan berinvestasi pada saham yang memiliki return tinggi dan prospek yang bagus dimasa mendatang (Ivani, 2019).

Beberapa penelitian terdahulu yang terkait dengan peristiwa pemilu atau pemilihan presiden diantara lain penelitian yang dilakukan oleh Lamasigi (2002). Dia melakukan penelitian tentang reaksi saham di BEJ (Bursa Efek Jakarta) terhadap Pergantian Presiden Republik Indonesia. Hasil penelitian menyatakan bahwa tidak terdapat perbedaan yang signifikan mengenai abnormal return sebelum pelaksanaan, dan setelah pelaksanaan. Penelitian yang sama namun dengan objek yang berbeda juga dilakukan oleh Ayudia Hanung Diniar dan Kiryanto (2014) yang melakukan penelitian pada Pemilihan Presiden tanggal 9 Juli 2014, dengan hasil penelitian yang menunjukkan bahwa Pemilihan Presiden cukup memberikan perubahan terhadap abnormal return saham dan TVA yang signifikan pada 5 hari sebelum dan sesudah pemilu. Sesudah Pemilihan Presiden, abnormal return saham lebih rendah dibanding sebelum Pemilihan Presiden (Manurrung, 2019). Pengujian kandungan informasi peristiwa Pemilihan Umum tahun 2014 terhadap aktivitas yang terjadi di bursa efek ini bertujuan untuk melihat reaksi pasar modal yang dapat diukur menggunakan abnormal return (Katti, 2018).

Berdasarkan beberapa penelitian diatas yang menyebutkan adanya perbedaan signifikan mengenai abnormal return sebelum pelaksanaan dan sesudah pelaksanaan, maka penelitian ini dilakukan dengan tujuan untuk membuktikan pengaruh pemilu presiden Indonesia tahun 2019 terhadap return saham ketika akan ditentukannya 
bakal calon presiden sebelum pelaksanaan pemilihan umum presiden, pada saat pelaksanaan, dan juga sesudah pelaksanaannya terhadap saham-saham yang terdaftar di JII70. Alasan dalam pemilihan saham JII70 yaitu sebagai objek penelitian karena indeks JII70 merupakan indeks saham unggulan di Bursa Efek Indonesia yang mempertimbangkan faktor likuiditas, kapitalisasi pasar, kinerja fundamental yang baik dengan jumlah sampel yang besar diharapkan dapat menginterpretasikan kondisi pasar modal di Indonesia. Berdasarkan uraian diatas, maka kami peneliti mengambil judul penelitian ini mengenai "Pengaruh Pelaksanaan Pemilu Presiden Indonesia Tahun 2019 Terhadap Return Saham JII70 di Indonesia".

\section{Landasan Teori}

\section{Pasar Modal}

Menurut Nor Hadi (2013:10) pasar modal merupakan sekelompok sistem keuangan yang terorganisir, yang didalamnya terdapat beberapa lembaga seperti bank-bank komersial dan juga surat berharga lainnya. Menurut Tandelilin (2010:26) pasar modal adalah tempat bertemunya pihak penjual dan pembeli modal dimana pihak yang membutuhkan dana akan memperjual-belikan aset sekuritasnya kepada pihak yang memiliki dana lebih. Sedangkan menurut Halim ((2015:1) pasar modal dapat didefinisikan sebagai pasar yang mempertemukan pihak yang menawarkan dan yang memerlukan dana jangka panjang, seperti saham dan obligasi. Sehingga, pasar modal merupakan suatu tempat yang terorganisir, tempat bertemunya pihak yang menawarkan dan memerlukan dana jangka panjang dengan memperjual-belikan berbagai instrumen keuangan seperti saham, obligasi, dan lain sebagainya. Pasar modal dikatakan memiliki manfaat dibidang keuangan karena memberikan suatu kemungkinan 
serta kesempatan mendapatkan imbalan (return) bagi pemilik dana sesuai dengan karakteristik investasi yang dipilih (Purnama dan Khairunnisa SE. 2015).

\section{Reaksi Pasar Modal}

Pasar akan bereaksi jika suatu peristiwa mengandung informasi. Suatu peristiwa dapat diibaratkan sebagai suatu kejutan (surprise) atau sesuatu yang tidak diharapkan (unexpected) (Dwianto dan Yulita 2019). Reaksi pasar modal ditentukan oleh informasi yang dihasilkan di pasar modal baik bad news maupun good news. Banyak peristiwa yang dapat mempengaruhi pergerakan return saham di pasar modal ketika ada peristiwa terjadi. Menurut Fahmi (2014:507) reaksi pasar investor dalam menanggapi informasi sangat dipengaruhi oleh berbagai informasi yang masuk, baik dalam segi ekonomi, politik, hukum, budaya, sosial, keamanan, dan berbagai informasi lainnya.

Menurut Lubis (2008:33) dampak peristiwa pemilu yang menyebabkan ketidakstabilan disebut sebagai salah satu dari market risk. Misalnya terjadi kerusuhan dalam pemilu karena terpilihnya presiden yang tidak pro pasar. Sedangkan menurut Asshodiqi (2015:24) bagi para pemilik dana, apabila keadaan politik cenderung tidak stabil, maka para pemilik dana akan lebih memilih memindahkan dananya ke Negara-negara yang memiliki keadaan politik yang lebih kondusif. Dengan hal ini, maka akan menyebabkan penarikan-penarikan besar-besaran dimana pada akhirnya akan berimplikasi pada ketidakstabilannya return saham di pasar modal.

Menurut Jogiyanto (2014:586) suatu pengumuman mengandung suatu informasi (information content), maka diharapkan pasar akan beraksi pada waktu pengumuman tersebut diterima oleh khalayak umum. Reaksi pasar modal dapat diukur dengan menentukan return sebagai transformasi nilai harga atau bisa juga dengan menggunakan abnormal return. Jika menggunakan abnormal returun, 
pengumuman yang mengandung suatu informasi akan memberikan abnormal return kepada pasar begitu juga sebaliknya.

\section{Efisiensi Pasar Modal}

Pasar modal yang efisien adalah kondisi ketika harga saham di pasar modal dapat merespon isu-isu yang beredar baik itu isu negatif maupun isu positif. Meskipun proses penyesuaian harga tidak harus berjalan dengan sempurna tetapi yang dipentingkan adalah harga yang terbentuk tidak bias (Pamungkas, Suhadak dan N.P 2015).

\section{Return}

Return merupakan hasil yang diperoleh dari investasi. Return sendiri berisi return realisasi atau return ekspektasi. Adapun yang menjadi perbedaan antara return realisasi dan return ekspektasi adalah terkait sifatnya, dimana return realisasi merupakan yang sifatnya sudah terjadi, sedangkan return ekspektasi sifatnya belum terjadi dari suatu investasi dalam periode yang telah ditentukan. Abnormal return merupakan kelebihan dari return realisasi terjadi terhadap return ekspektasi (Taufika Nur Widyasari,. dkk, 2017).

\section{Aktivitas Volume Perdagangan (Trading Volume Activity)}

Untuk membuat keputusan investasi, investor akan memeprtimbangkan risiko dan tingkat keuntungan yang diharapkan. Sehingga investor membutuhkan informasi untuk melakukan analisis saham. Dengan adanya informasi yang beredar di pasar saham akan mengubah keyakinan para investor untuk membuat suatu keputusan. Setiap informasi yang diperoleh para investor akan menghasilkan suatu reaksi pasar, dimana reaksi pasar tersebut dapat dilihat dari aktivitas volume perdagangan saham. Aktivitas volume perdagangan merupakan suatu alat yang digunakan untuk 
mengukur tingkat kegiatan jual beli saham di lantai bursa (Luhur 2010).

Trading Volume Activity adalah kegiatan penjualan yang terjadi di bursa saham pada waktu tertentu dan merupakan salah satu variabel yang mempengaruhi suatu pergerakan harga saham. Volume perdagangan saham merupakan tingkat besarnya jumlah lembar saham yang diperdagangkan pada waktu tertentu. Semakin besar jumlah saham yang diperjualbelikan, maka saham tersebut dapat dikatakan aktif karena sering ditransaksikan dipasar modal. Trading volume activity (volume perdagangan saham) yaitu indikator yang digunakan untuk mengukur likuiditas suatu saham. Apabila secara statistik perdagangan saham beberapa hari setelah peristiwa terdapat peningkatan dibanding beberapa hari sebelum peristiwa, maka dapat dikatakan bahwa terdapat peningkatan likuiditas perdagangan saham setelah terjadinya suatu peristiwa (Akbar, Saerang dan Maramis 2019).

Aktivitas volume perdagangan juga menjadi salah satu elemen penting dalam melakukan perkiraan yang digunakan sebagai bagian dari informasi yang memberikan signal pergerakan harga yang akan datang dimana harga saham pershare tidak dapat disampaikan kepada pelaku pasar (Ivani, 2019, hal. 4).

\section{Abnormal Return}

Abnormal Return adalah keuntungan dari return yang sesungguhnya terhadap return normal, sedangkan return normal merupakan return yang diharapkan oleh para pemilik modal (expected return). Return tidak normal atau abnormal return merupakan selisih antara return sesungguhnya yang terjadi dengan return ekspektasi (Hartono, 2008) (Liwe, Tommy dan Maramis 2018). 


\section{Metode Penelitian}

\section{Jenis Penelitian}

Penelitian ini adalah penelitian kuantitatif yaitu menekankan analisis pada data-data angka yang diolah dengan menggunakan metode statistik. Jenis penelitian ini adalah studi peristiwa (event study) yaitu studi yang mempelajari reaksi pasar terhadap suatu peristiwa (event) yang informasinya diinformasikan sebagai pengumuman. Jenis data yang digunakan dalam penelitian ini adalah data sekunder, yaitu data yang diperoleh dari pihak lain yang bersifat time series. Data ini berupa dokumen dan informasi yang berhubungan dengan objek penelitian yaitu data harga saham pada saat pembukaan dan penutupan. Fokus pada penelitian ini adalah dampak return saham yang diakibatkan oleh peristiwa pelaksanaan pemilu presiden pada tahun 2019.

\section{Sumber Data}

Sumber data pada penelitian ini menggunakan data yang dipublikasikan di website Bursa Efek Indonesia www.idx.co.id. Alasan dalam pemilihan sumber data di Bursa Efek Indonesia karena Bursa Efek Indonesia merupakan pusat informasi perusahaan yang go public di Indonesia sehingga disana tersedia berbagai sumber data yang diperlukan secara akurat. Teknik pengumpulan datanya meliputi pencatatan harga saham pada saat penutupan (closing price).

\section{Populasi dan Sampel Penelitian}

Sampel yang digunakan dalam penelitian ini adalah perusahaan-perusahaan yang terdaftar sebagai anggota JII70 di Bursa Efek Indonesia (BEI). Pengambilan sampel penelitian ini menggunakan teknik purposive sampling yaitu 
penarikan sampel yang dilakukan secara sengaja berdasarkan pertimbangan yang telah ditetapkan. Kriteria yang ditetapkan oleh peneliti adalah sebagai berikut:

1. Tercatat sebagai anggota indeks JII70 selama periode penelitian.

2. Aktif ditransaksikan selama periode penelitian.

Berdasarkan kriteria tersebut maka sampel penelitian yang diperoleh dari perusahaan yang hanya menjadi anggota JII70. Berdasarkan hasil pemilihan sampel, yang akan menjadi sampel dalam penelitian adalah perusahaan yang tergabung didalam indeks JII70 tersebut yang mengalami kenaikan maupun penurunan secara signifikan dalam jangka waktu yang telah ditentukan.

\section{Teknik Analisis Data}

Alat analisis dan perhitungan return saham yang digunakan dalam penelitian ini adalah pengujian abnormal return. Pengolahan data dan per hitungan data dilakukan dengan menggunakan program Microsoft Excel serta SPSS. Tahap-tahapnya berdasar event study, yaitu:

1. Menentukan sampel.

2. Mengidentifikasi di hari sebelum pelaksanaan pemilihan umum presiden 2019, pada saat pelaksanaan, dan juga sesudah pelaksanaannya terhadap saham-saham yang terdaftar di JII70.

3. Menghitung market return (return pasar) per hari selama periode peristiwa, dengan menggunakan rumus: 


$$
\text { Return }=\frac{\mathrm{P}_{t}-\mathrm{P}_{t-1}}{\mathrm{P}_{t-1}}
$$

\section{PeriodePenelitian}

Periode penelitian yang dilakukan untuk meneliti peristiwa pemilu presiden 2019 ini adalah selama akan ditentukannya bakal calon presiden, sebelum pelaksanaan pemilihan umum presiden 2019, pada saat pelaksanaan, dan juga sesudah pelaksanaannya terhadap saham-saham yang terdaftar di JII70. Alasan pengambilan waktu tersebut karena disekitar peristiwa tersebut dianggap merupakan waktu yang rawan bagi investor untuk melakukan kegiatan perdagangan dipasar modal, selain itu event window yang lebih panjang akan lebih menyulitkan peneliti karena dikhawatirkan kejadian yang diteliti akan tercampur dengan kejadian yang lain sehingga kejadian yang diteliti akan menjadi biasa.

\section{Pembahasan}

Berikut adalah indeks harga saham sebelum dan sesudah pelaksanaan pemilu Presiden Indonesia pada tahun 2019 yang diperoleh dari www.idx.co.id.

Tabel 1.2 : Daftar Indeks Saham JII70

\begin{tabular}{ccccc}
\hline No & DATE & KODE INDEKS & OPEN & CLOSE \\
\hline 1 & $06 / 08 / 2018$ & JII70 & 220,222 & 224,065 \\
2 & $07 / 08 / 2018$ & JII70 & 224,065 & 222,656 \\
3 & $08 / 08 / 2018$ & JII70 & 223,472 & 222,471
\end{tabular}




\begin{tabular}{|c|c|c|c|c|}
\hline 4 & 09/08/2018 & JII70 & 232,197 & 222,445 \\
\hline 5 & $10 / 08 / 2018$ & JII70 & 222,445 & 222,607 \\
\hline 6 & $13 / 08 / 2018$ & JII70 & 222,607 & 214,066 \\
\hline 7 & $14 / 08 / 2018$ & JII70 & 214,331 & 208,145 \\
\hline 8 & $10 / 04 / 2019$ & JII70 & 235,922 & 235,913 \\
\hline 9 & $11 / 04 / 2019$ & JII70 & 235,913 & 232,133 \\
\hline 10 & $12 / 04 / 2019$ & JII70 & 232,133 & 231,543 \\
\hline 11 & $15 / 04 / 2019$ & JII70 & 231,543 & 231,994 \\
\hline 12 & $16 / 04 / 2019$ & JII70 & 231,994 & 234,36 \\
\hline 13 & $18 / 04 / 2019$ & JII70 & 234,36 & 234,779 \\
\hline 14 & $22 / 04 / 2019$ & JII70 & 237,779 & 230,152 \\
\hline 15 & $23 / 04 / 2019$ & JII70 & 230,152 & 233,397 \\
\hline 16 & $24 / 04 / 2019$ & JII70 & 233,397 & 232,408 \\
\hline 17 & $25 / 04 / 2019$ & JII70 & 232,408 & 228,551 \\
\hline 18 & $26 / 04 / 2019$ & JII70 & 228,551 & 229,552 \\
\hline 19 & $29 / 04 / 2019$ & JII70 & 229,552 & 228,937 \\
\hline 20 & $30 / 04 / 2019$ & JII70 & 228,937 & 230,072 \\
\hline 21 & $02 / 05 / 2019$ & JII70 & 230,072 & 227,767 \\
\hline 22 & 03/05/2019 & JII70 & 227,767 & 224,805 \\
\hline 23 & $21 / 05 / 2019$ & JII70 & 207,357 & 208,654 \\
\hline 24 & $21 / 10 / 2019$ & JII70 & 232,393 & 232,907 \\
\hline
\end{tabular}


Berikut adalah hasil perhitungan return saham:

Tabel 1.2 : Hasil Perhitungan Return

\begin{tabular}{|c|c|c|c|c|c|}
\hline No & DATE & $\begin{array}{c}\text { KODE } \\
\text { INDEKS }\end{array}$ & OPEN & CLOSE & RETURN \\
\hline 1 & $03 / 08 / 2018$ & JII70 & & 221,591 & 0 \\
\hline 2 & 06/08/2018 & JII70 & 220,222 & 224,065 & 0,0112 \\
\hline 3 & 07/08/2018 & JII70 & 224,065 & 222,656 & $-0,0063$ \\
\hline 4 & 08/08/2018 & JII70 & 223,472 & 222,471 & $-0,0008$ \\
\hline 5 & 09/08/2018 & JII70 & 232,197 & 222,445 & $-0,0001$ \\
\hline 6 & $10 / 08 / 2018$ & JII70 & 222,445 & 222,607 & 0,0007 \\
\hline 7 & $13 / 08 / 2018$ & JII70 & 222,607 & 214,066 & $-0,0384$ \\
\hline 8 & $14 / 08 / 2018$ & JII70 & 214,331 & 208,145 & $-0,0277$ \\
\hline 9 & $10 / 04 / 2019$ & JII70 & 235,922 & 235,913 & 0,1334 \\
\hline 10 & $11 / 04 / 2019$ & JII70 & 235,913 & 232,133 & $-0,0160$ \\
\hline 11 & $12 / 04 / 2019$ & JII70 & 232,133 & 231,543 & $-0,0025$ \\
\hline 12 & $15 / 04 / 2019$ & JII70 & 231,543 & 231,994 & 0,0019 \\
\hline 13 & $16 / 04 / 2019$ & JII70 & 231,994 & 234,36 & 0,0102 \\
\hline 14 & $18 / 04 / 2019$ & JII70 & 234,36 & 234,779 & 0,0018 \\
\hline
\end{tabular}

Volume 4 , No. 2, Juni 2020 


\begin{tabular}{cccccc}
15 & $22 / 04 / 2019$ & JII70 & 237,779 & 230,152 & $-0,0197$ \\
16 & $23 / 04 / 2019$ & JII70 & 230,152 & 233,397 & 0,0141 \\
17 & $24 / 04 / 2019$ & JII70 & 233,397 & 232,408 & $-0,0042$ \\
18 & $25 / 04 / 2019$ & JII70 & 232,408 & 228,551 & $-0,0166$ \\
19 & $26 / 04 / 2019$ & JII70 & 228,551 & 229,552 & 0,0044 \\
20 & $29 / 04 / 2019$ & JII70 & 229,552 & 228,937 & $-0,0027$ \\
21 & $30 / 04 / 2019$ & JII70 & 228,937 & 230,072 & 0,0050 \\
22 & $02 / 05 / 2019$ & JII70 & 230,072 & 227,767 & $-0,0100$ \\
23 & $03 / 05 / 2019$ & JII70 & 227,767 & 224,805 & $-0,0130$ \\
24 & $21 / 05 / 2019$ & JII70 & 207,357 & 208,654 & $-0,0718$ \\
25 & $21 / 10 / 2019$ & JII70 & 232,393 & 232,907 & 0,1162 \\
\hline
\end{tabular}

Dari tabel diatas dapat dijelaskan sebagai berikut:

A. Pada saat pendaftaran calon Presiden:

1. Pada tanggal 06 Agustus 2018, Return saham senilai 0,0112

2. Pada tanggal 07 Agustus 2018, Return saham senilai $-0,0063$

3. Pada tanggal 08 Agustus 2018, Return saham senilai $-0,0008$

4. Pada tanggal 09 Agustus 2018, Return saham senilai -0,0001

5. Pada tanggal 10 Agustus 2018, Return saham senilai 0,0007

6. Pada tanggal 13 Agustus 2018, Return saham senilai $-0,0384$ 
7. Pada tanggal14 Agustus 2018, Return saham senilai $-0,0277$

B. Pada saat seminggu sebelum dan seminggu sesudah peristiwa:

1. Pada tanggal 10 April 2019, Return saham senilai 0,1334

2. Pada tanggal 11 April 2019, Return saham senilai $-0,0160$

3. Pada tanggal 12 April 2019, Return saham senilai $-0,0025$

4. Pada tanggal 15 April 2019, Return saham senilai 0,0019

5. Pada tanggal 16 April 2019, Return saham senilai 0,0102

6. Pada tanggal 18 April 2019, Return saham senilai 0,0018

7. Pada tanggal 22 April 2019, Return saham senilai $-0,0197$

8. Pada tanggal 23 April 2019, Return saham senilai 0,0141

9. Pada tanggal 24 April 2019, Return saham senilai $-0,0042$

10. Pada tanggal 25 April 2019, Return saham senilai $-0,0166$

11. Pada tanggal 26 April 2019, Return saham senilai 0,0044

12. Pada tanggal 29 April 2019, Return saham senilai $-0,0027$

13. Pada tanggal 30 April 2019, Return saham senilai 0,0050 
14. Pada tanggal 02 Mei 2019, Return saham senilai0,0100

15. Pada tanggal 03 Mei 2019, Return saham senilai 0,0130

C. Pada saat pengumuman pemenang Presiden:

1. Pada tanggal 21 Mei 2019, Return saham senilai 0,0718

D. Pada saat pelantikan Presiden:

1. Pada tanggal 21 Oktober 2019, Return saham senilai 0,1162

Berikut adalah grafik indeks harga saham dari saat penentuan bakal calon presiden sampai dengan pelantikan presiden:

\section{Daftar Harga Saham Indeks JII70 pada Masa Pengumuman Bakal Calon Presiden}

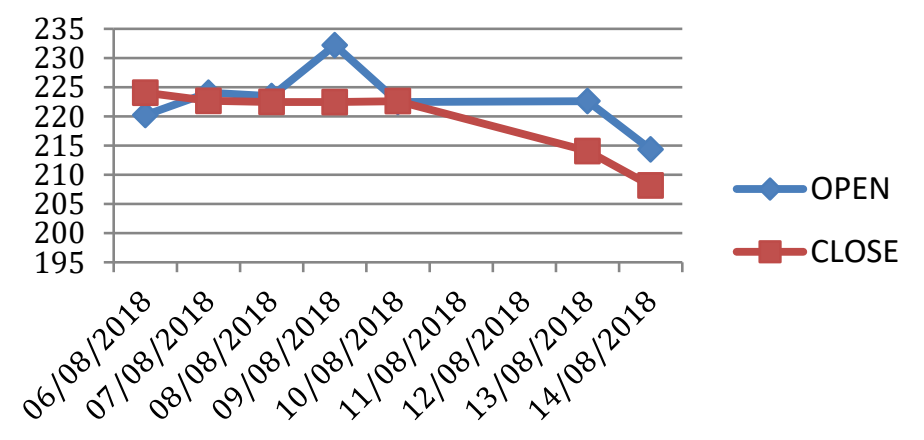

Penjelasan grafik 2.1:

1. Harga saham pembukaan pada 6 Agustus 2018 seharga 220.222, dan pada saat penutupan senilai 
224.065. Sehingga menunjukkan kenaikan senilai 3.843.

2. Harga saham pembukaan pada 7 Agustus 2018 seharga 224.065, dan pada saat penutupan senilai 222.656. Sehingga menunjukkan penurunan senilai 1.409 .

3. Harga saham pembukaan pada 8 Agustus 2018 seharga 223.472. dan pada saat penutupan senilai 222.471. Sehingga menunjukkan penurunan senilai 1.001 .

4. Harga saham pembukaan pada 9 Agustus 2018 seharga 232.197, dan pada saat penutupan senilai 222.445. Sehingga menunjukkan penurunan senilai 9.752.

5. Harga saham pembukaan pada 10 Agustus 2018 seharga 222.445, dan pada saat penutupan senilai 222.607. Sehingga menunjukkan kenaikan senilai 0.162 .

6. Harga saham pembukaan pada 13 Agustus 2018 seharga 222.607, dan pada saat penutupan senilai 214.066. Sehingga menunjukkan penurunan senilai 8.541.

7. Harga saham pembukaan pada 14 Agustus 2018 seharga 214.331, dan pada saat penutupan senilai 208.145. Sehingga menunjukkan penurunan senilai 6.186. 
Grafik 2.2

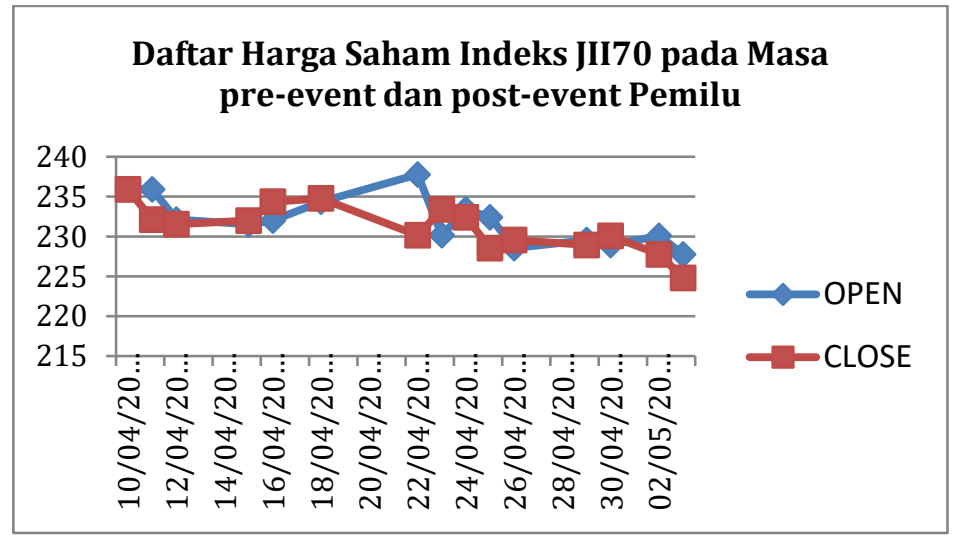

Penjelasan grafik 2.2:

1. Harga saham pembukaan pada H-7 sebelum pelaksanaan pemilu seharga 235.922, dan harga saham penutupannya senilai 235.913. Sehingga menunjukkan penurunan senilai 0.9

2. Harga saham pembukaan pada H-6 sebelum pelaksanaan pemilu seharga 235.913, dan harga saham penutupannya senilai 232.133. Sehingga menunjukkan penurunan senilai 3.78.

3. Harga saham pembukaan pada H-5 sebelum pelaksanaan pemilu seharga 232.133, dan harga saham penutupannya senilai 231.543. Sehingga menunjukkan penurunan senilai 0.59.

4. H-4 tanggal 13 April 2019 jatuh pada hari Sabtu (bukan hari bursa).

5. H-3 tanggal 14 April 2019 jatuh pada hari Minggu (bukan hari bursa).

6. Harga saham pembukaan pada H-2 sebelum pelaksanaan pemilu seharga 231.543, dan harga 
saham penutupannya senilai 231.994. Sehingga menunjukkan kenaikan senilai 0.451 .

7. Harga saham pembukaan pada $\mathrm{H}-1$ sebelum pelaksanaan pemilu seharga 231.994, dan harga saham penutupannya senilai 234.36. Sehingga menunjukkan kenaikan senilai 2.366.

Analisis penurunan pada perusahaan AALI adalah Pada saat H-7 pemilu pergerakan harga saham cukup stabil, akan tetapi pada $\mathrm{H}+1$ pemilu harga saham perusahaan AALI mulai mengalami penurunan sebesar Rp 125. Hal tersebut berlanjut pada penurunan selama $\mathrm{H}+7$ pemilu dimana harga saham mengalami penurunan yang sangat drastis yaitu mencapai harga $\operatorname{Rp} 10.752$.

Analisis penurunan pada perusahaan ACES adalah sebagai berikut:

Pada saat $\mathrm{H}-7$ sampai dengan $\mathrm{H}+1$ pemilu pergerakan harga saham cenderung mengalami penurunan. Dengan harga akhir di $\mathrm{H}+7$ pemilu adalah senilai RP 1.600 dari yang harga sebelum pemilu sebesar Rp 1.860.

Analisis penurunan pada perusahaan KLBF adalah sebagai berikut:

Pada saat H-7 pemilu pergerakan harga saham mengalami penurunan. Penurunan terbanyak terjadi pada $\mathrm{H}-$ 6 pemilu, dimana harga saham jatuh ke Rp 1.515. Hal tersebut berlanjut hingga pada penurunan selama $\mathrm{H}+7$ pemilu dimana harga saham mengalami penurunan mencapai harga $\mathrm{Rp}$ 1.470 . 


\section{Analisis penurunan pada perusahaan INTP adalah sebagai berikut:}

Pada saat H-7 pemilu menuju H-6 pemilu pergerakan harga saham cukup mengalami penurunan yang drastis senilai Rp 700. Begitu juga dari H-6 menuju H-5 yang mengalami penuruanan sebesar Rp 700. Akan tetapi pada $\mathrm{H}+1$ pemilu harga saham perusahaan INTP mulai mengalami kenaikan sebesar Rp 350. Lalu, menuju $\mathrm{H}+7$ pemilu harga saham mengalami penurunan yang cukup drastis yaitu senilai $\mathrm{Rp} 800$.

\section{Analisis penurunan pada perusahaan UNVR adalah sebagai berikut:}

Pada saat H-7 pemilu menuju H-6 pemilu pergerakan harga saham cukup mengalami penurunan senilai $\mathrm{Rp} 800$. Akan tetapi pada $\mathrm{H}-5$ pemilu mengalami kenaikan sebesar Rp 950. Pada H-1 menuju $\mathrm{H}+1$ pemilu cenderung naik, akan tetapi pada $\mathrm{H}+7$ pemilu harga saham perusahaan UNVR mulai mengalami penurunan sebesar Rp 3000 dengan harga saham yang mencapai Rp 46.400 .

\section{Analisis kenaikan pada perusahaan ITMG adalah sebagai berikut:}

Pada saat H-7 menuju H-6 pemilu pergerakan harga saham mengalami kenaikan sebesar $\operatorname{Rp} 300$, dan dari H-6 menuju H-5 mengalami kenaikan lagi sebesar Rp 425. Akan tetapi pada saat $\mathrm{H}+1$ pemilu, harga saham mengalami penurunan hingga berada di angka Rp 19.725. Lalu, pada saat $\mathrm{H}+6$ dan $\mathrm{H}+7$ pemilu harga saham mulai mengalami kenaikan dengan harga Rp 20.225 


\section{Analisis kenaikan pada perusahaan UNTR adalah sebagai berikut:}

Pada saat H-7 menuju H-6 pemilu pergerakan harga saham mengalami penurunan sebesar Rp 600. Hingga pada H-1 pemilu harga saham mengalami kenaikan sehingga menunjukkan harga $\mathrm{Rp}$ 26.452. Akan tetapi pada saat $\mathrm{H}+1$ pemilu, harga saham mengalami sedikit penurunan. Lalu, pada saat $\mathrm{H}+6$ dan $\mathrm{H}+7$ pemilu harga saham mulai kembali mengalami kenaikan dengan harga Rp 27.675.

\section{Penutup}

Pemilihan presiden pada tanggal 17 April 2019 terdapat perbedaan signifikan pada harga saham. Harga saham pembukaan pada $\mathrm{H}-7$ sebelum pelaksanaan pemilu menunjukkan penurunan senilai 0.9. Setelah itu harga saham setelah pelaksanaan pemilu pada saat pembukaan pengumuman pemenang presiden tanggal 21 Mei 2019 harga saham penutupannya menunjukkan kenaikan harga saham senilai 1.297. Sedangkan harga saham pembukaan pada saat pelantikan presiden tanggal 21 Oktober 2019 harga saham penutupannya menunjukkan kenaikan senilai 0.514 .

Jika dilihat dari reaksi per hari dari seorang investor selama 24 hari return pemilu presiden 2019 sebelum, sesudah peristiwa pemilu dan pada saat pengumuman pemenang presiden mengalami penurunan sedangkan return pada pelantikan presiden mengalami kenaikan. Keterbatasan pada penelitian ini yaitu pada jumlah sampel penelitian yang terlalu sedikit serta dalam periode waktu pengamatan yang pendek yaitu 7 hari pada saat pendaftaran calon presiden, 7 hari sebelum peristiwa pemilu, 1 hari pada saat peristiwa pemilu, 7 hari setelah peristiwa pemilu, 1 hari saat 
pengumuman pemenang presiden, dan 1 hari saat pelantikan presiden.

\section{Daftar Referensi}

Liwe Christa T.S., Parengkuan Tommy, Joubert B. Maramis. 2018. “Reaksi Investor Dalam Pasar Modal Atas Peristiwa Menguatnya Kurs Dolar Amerika Serikat Terhadap Nilai Tukar Rupiah Pada 26 Agustus 2015". Jurnal EMBA. Vol.6 No.3. 1060.

Diniar, Ayudia Hanung, Kiryanto. 2015. “Analisis Dampak Pemilu Presiden Jokowi Terhadap Return Saham". Jurnal Akuntansi Indonesia. Vol. 4. No. 2. 97.

Akbar Erica P., Ivonne S. Saerang, Joubert B. Maramis. 2019. "Reaksi Pasar Modal Terhadap Pengumuman Kemenangan Presiden Joko Widodo Berdasarkan Keputusan Kpu Pemilu Periode 2019-2024". Jurnal Ilmiah Manajemen Bisnis dan Inovasi. Vol. 6. No. 2. 125.

Mentayani, Ida. 2016. "Analisis Perbedaan Harga Saham Sebelum Dan Sesudah Pemilihan Umum Presiden 2014". Jurnal Ekonomi dan Bisnis. Vol. 9. No. 1. 106.

Dwianto, Nicholas Arditya, Ima Kristina Yulita. 2019. “Reaksi Pasar Modal Indonesia Terhadap Peluncuran Rudal Korea Utara". Journal of Reseaarch in Business and Economics. Vol. 2. No. 1. 26.

Pamungkas, Aryo, Suhadak, M.G Wi Endang N.P. 2015. "Pengaruh Pemilu Presiden Indonesia Tahun 2014 
Terhadap Abnormal Return Dan Trading Volume Activity". Jurnal Administrasi Bisnis. Vol. 20. No. 1.3.

Purnama, Yoga Satya dan Khairunnisa SE., MM. 2015. "Reaksi Pasar Modal Indonesia Terhadap Pengumuman Hasil Pemilihan Umum Presiden 2009 Dan 2014 Pada Bursa Efek Indonesia". Jurnal eproceeding of Management. Vol. 2. No. 1. 247.

Luhur Suryo. 2010. "Reaksi Pasar Modal Indonesia Seputar Pemilihan Umum 8 Juli 2009 pada Saham LQ45". Jurnal Keuangan dan Perbankan. Vol. 14. No. 2. 252.

Alrhafynza, Fima Bara, dan Ely Siswanto. 2017. “Reaksi Pasar Modal Indonesia Terhadap Peristiwa Politik Nasional".Seminar Nasional Manajemen dan Bisnis Ke3.47-57.

Ivani, Nurul Saadah. 2019. "Pengaruh Pemilu Presiden Indonesia Tahun 2019 Terhadap Abnormal Return Dan Tranding Volume Activity Study Pada Saham Lq45". Jurnal Al-Qarh. 2-14.

Katti, Siti Wardhani Bakri. 2018. "Pengaruh Peristiwa Politik (Pemilu Presiden Dan Pengumuman Susunan Kabinet) Terhadap Saham Sektor Industri Di Bursa Efek Indonesia". Jurnal Capital. 126-134.

Manurrung, Harris. 2019. "Pengaruh Pemilu Serentak Terhadap Return Saham Di Indonesia". Jurnal for Business and Entrepreneur. 12-28. 
Rofiki, David. Topowijoyo dan Ferina Nurlaily. 2018. “Reaksi Pasar Modal Indonesia Akibat Peristiwa Pemilihan Gubernur Dki Jakarta Putaran Ii 2017". Jurnal Administrasi Bisnis. 1-8.

Widyasari, Taufika Nur. dkk. 2017. “Analisis Reaksi Pasar Modal Atas Peristiwa Kebijakan Amnesti Pajak 2016". Jurnal Administrasi Bisnis. 139.

https://www.idx.co.id 